Portland State University

PDXScholar

1972

\title{
Factors affecting the population of raptorial birds on Sauvie Island, Oregon
}

Jeffry Gottfried

Portland State University

Follow this and additional works at: https://pdxscholar.library.pdx.edu/open_access_etds

Part of the Ecology and Evolutionary Biology Commons, and the Ornithology Commons Let us know how access to this document benefits you.

\section{Recommended Citation}

Gottfried, Jeffry, "Factors affecting the population of raptorial birds on Sauvie Island, Oregon" (1972). Dissertations and Theses. Paper 965.

https://doi.org/10.15760/etd.965

This Thesis is brought to you for free and open access. It has been accepted for inclusion in Dissertations and Theses by an authorized administrator of PDXScholar. Please contact us if we can make this document more accessible: pdxscholar@pdx.edu. 
AN AESTRACl OF THE PAESIS OF Jeffry Gottfrled for the vaster of Sclence 1r Blology presented December 8, 1972 .

Title: Factors A"fecting tie Population of Raptorial Blrds on Sauvle Island, Uregon.

AFFROVED BY MEVEERS OF THE THESIS COMITTEE:

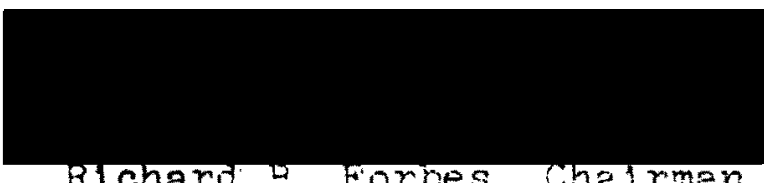

Blchard L. Forbes, Chatrman
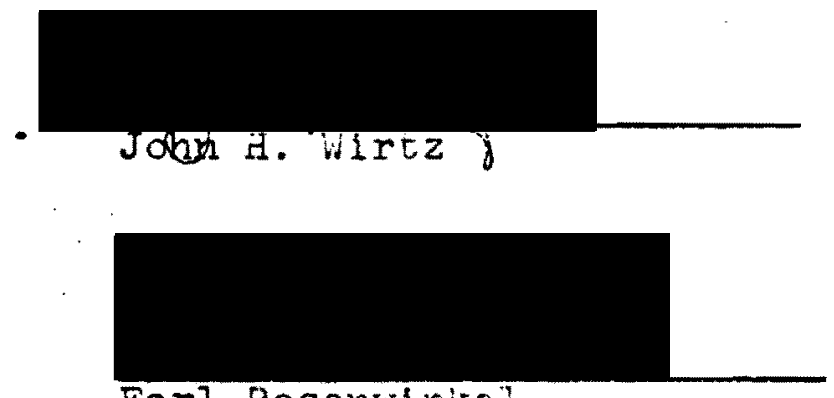

Earl Rosenwinkel

This study is an analysis of the varlous factors a fecting the population of raptorlal birds on Sauvle Island, creeron. A census of diurnal and nocturnal raptors was carried out along with an analysis of food habits: Once the major prey specles were determined they were censused and the effects of the land ranagement practices on their numbers was investigated. In addition, 100 randomly selected nest boxes were sampled so as to determine the extent to wnlch raptors were maklne use of them. Red-talled tiawk and Great dorred Owl nests were located.

It was found that four dlurnal raptors and three nocturnal raptors were present in sizeable numbers on Sauvie 
Island duning the winter and spring of 1972. In addition trere were iess cominon sightings of rour diurral and one nocturnal raptor.

The most common food item of raptors in general was the vole, Microtus townsendi, which was later found to be present in extremely high numbers.

The common practice of planting flelds of srains and the intentional floodins of them (for waterfowl use) was found to be a major factor in the numbers and vulnerability of Microtus townsend1.

Ducks were a common food ltem for all rartorla? srecies during and immedlately after duc's huntinc season, but not at any other time of year which seened to indicate that the raptors were feeding on carrion or wounded ducks.

It was found that Barn Owls (Tyto alba). Screech cwls (ctis asic) and Kestrel (Falco sparvarlus) nade use of the nest boxes on Sauvie Island.

The overlapping of food hablts of Sauvle Island raptors was discussed and an attempt was made to reconclie the apparent contradiction to Gause's Rule. 
FACTORS APFECTING TAE FOFULATION OF RAFTORIAL BIRDS ON SAUVIE ISIAND, OREGON

\author{
by \\ JEFFRY GODTFAIED
}

A thesis submitted in partial fulfillment of the requirements for the dezree of

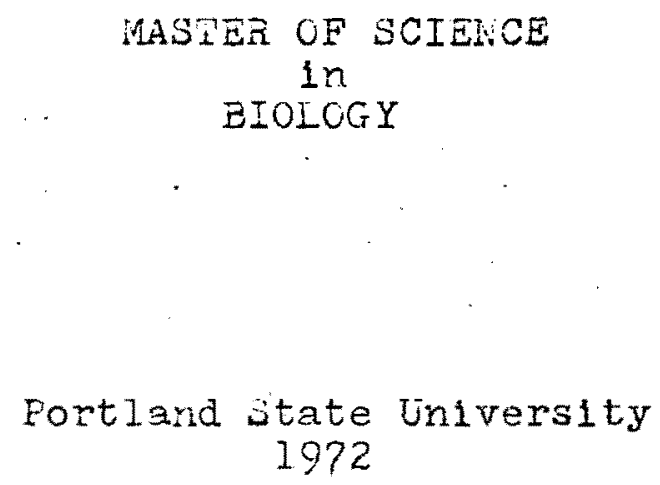




\section{TO THE OFFICE OF GRADUATE STUDIES:}

The members of the Committee anprove the thesis of Jeffry Gottfried presented December 8, 1972.
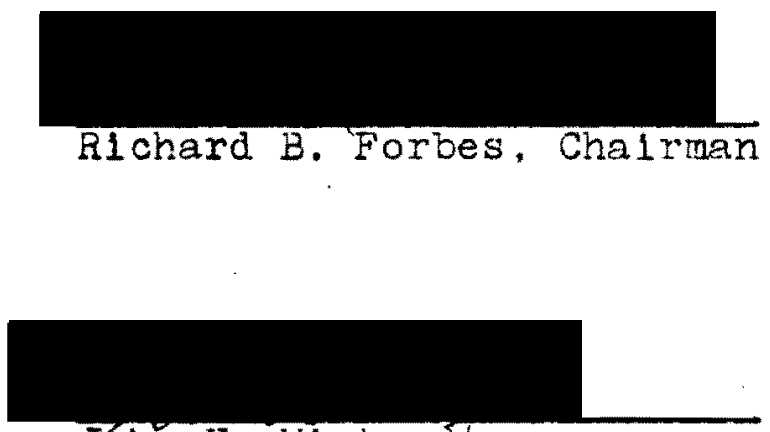

Jehin H. Wirtz $y$

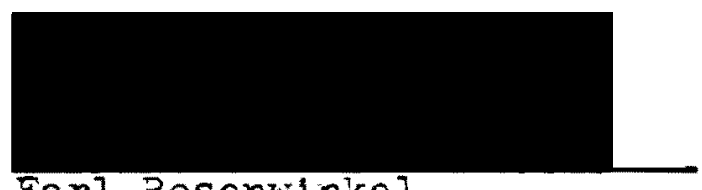

Earl Rosenwinkel

\section{AFFECVD:}
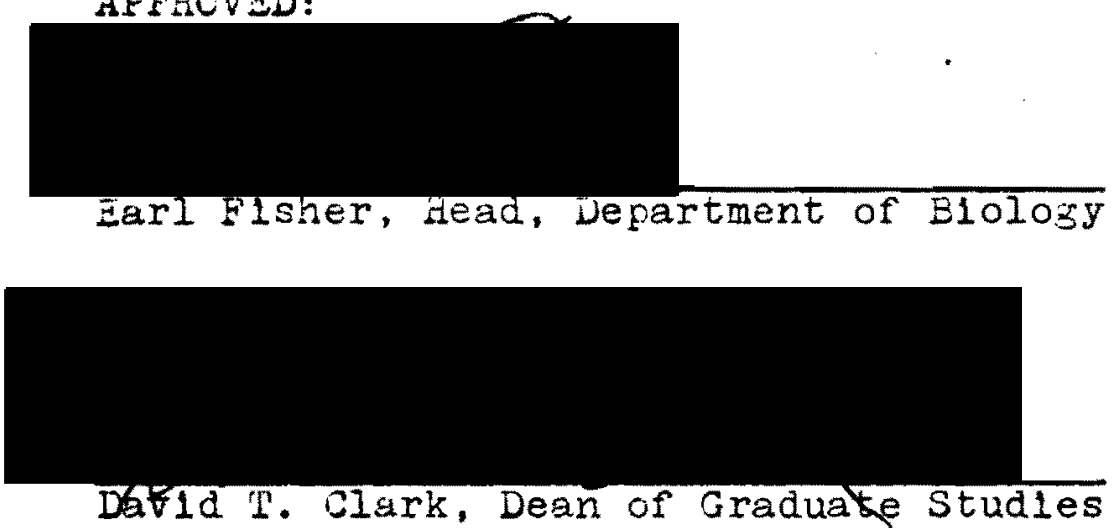


\section{ACWNWI EDGHENIS}

I wish to express my sincere thank: to Dr. Richard Forbes, ny professor, for the hel? he has riven ne botn In the fleld stage and in the writing stare of this thesis: to Mr. Tom Davis of the Sol1 Conservotion Service whose mony years of service to Bauvie Island have made him a wealth of knowledge on the ecology of the Island and an invaluade resource person for me; to Mr. Frank liewton and Mr. Worm dinniok of the oregon State Game Commission who taught me a great deal about the wildilfe and ecoingy of Sauvie Island and without whose cooperation this study would be lmpossibie; srd finally, to Warren aney, siso of the oregon state Gane Comisston, for his suggestions on census techriques. 


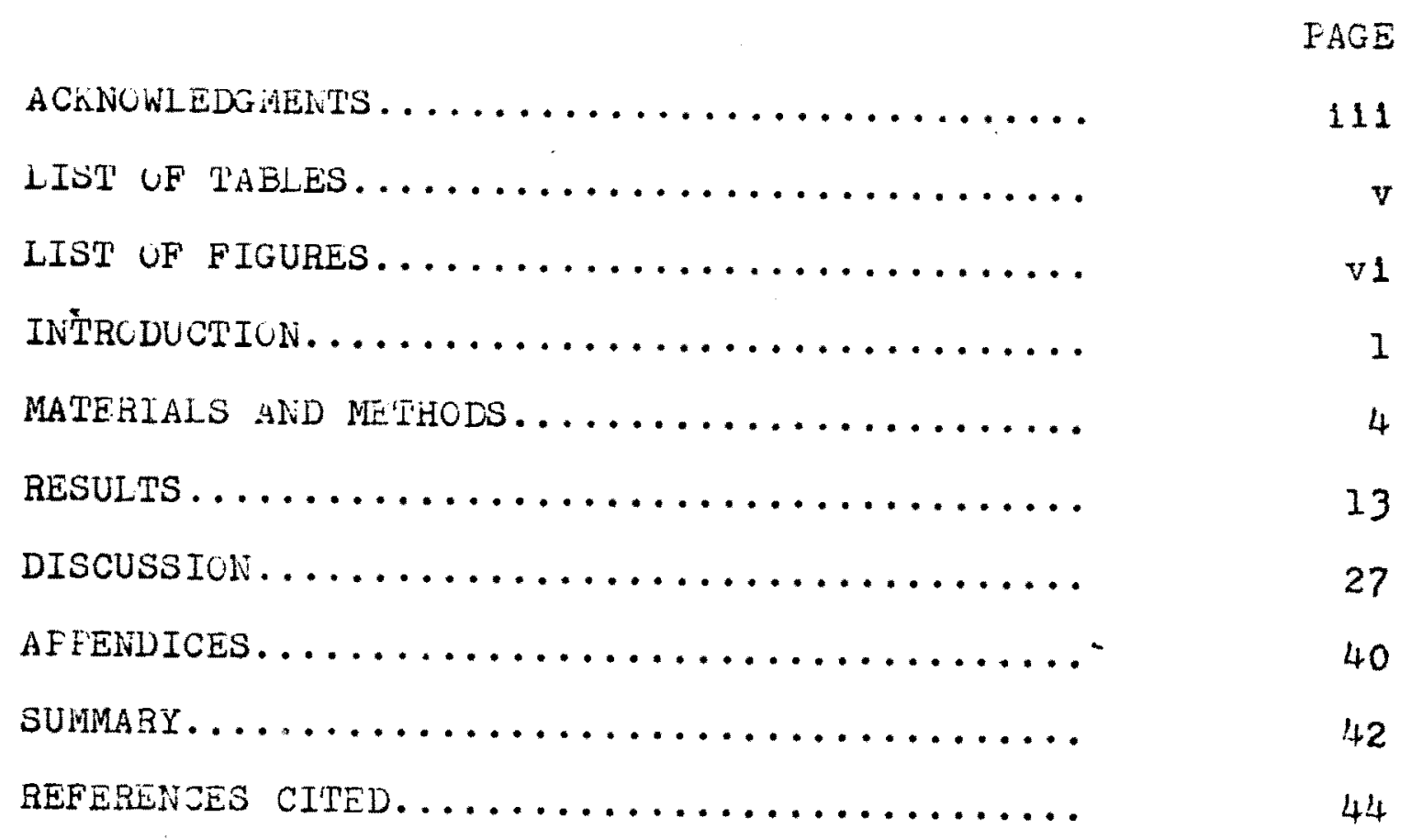




\section{LIST OF TABIES}

TABIE

I

II

III

IV
Census Data, Diurnal Raptors

Raptor Food Hablts

Results of Traoping in Freviously Flooded Fields

Owl Census
PAGE

7.6

18

23

26 


\section{IIST OF FIGURES}

FIGURE

FAGE

I

Map of Sauvie Island

3

II

Graph, Columbia River Iigh Water

III

Graph, Rodent Activity in Flooded and Non-Flooded Areas

24 


\section{IMTREDCTIOIV}

For a number of yeirs sclentiflc joumals as well as perular 11 terature have reported that the raptors, or birds of prey, are on the decline both in the United states and worldwide. Ferguson-Lees (1963) documented decinirig numbers of Guropean raptors and listed habitat cestruction, polsoning by pesticldes and industrial pollutants and shooting by hunters as the major causes of the decline of Euronean raptors. Dewitt and Buckley (1955) in their study of the Bald Escle (Hallaecetus leucoceshalus) in North Amerlca, and Spltzer (Ir Limmerman 1971) in his study of the osprey (pandion halliaetus) In Eastern North Anerica both found chemical pollutants of one type or another to be the cause of the declining numbers of these two species of raptors. Birds of prey, like ali other predators, feed near the tor of food chains and are therefore subjected to the hlghest levels of chemlcal. toxicants that are concentrated at each level of the food chain (Feterson, in Grossmar and Harlet, 1964). ihere have been documented reports of chemical pollutant residues found on analyses in the bodles of Buzzards (Buteo buteo), Sperrow Hawks (Acciciter nisus), European Kestrels (Falco tinruncu?us). Feregrine Falcons (Falco gerezrinus), Bald Eagles (Hal lacetus leucocerhalus). Long-eared owls (As10 otus). Tawny owls (Sitrix aluoo). Little Owls (Athere noctus), and Osvrey (Eandion 
hallaetus), (Cramps 1963; Dewltt and Buckley 1955: Jeffries and Prestt 1966; Z1mmerman 1971).

In addition to the pesticide problems, blrds of nrey are faced with the problem of habltat destruction caused directly or indirectly by man's growing numbers and the spreading of cities into once natural areas.

The references clted above paint a very gioomy plcture for the future of the raptors. At a time such as this it is important that healthy, productive raptor populations and their habltats be ldentifled and studied so that as much information as possible can be obtalned about the ecology of the varlous specles of raptors and of their environment. Hopefully, with increased knowledge of the factors that constitute good raptor habitat steps can be taken to preserve sultable habltats and encourage the increase of these magniflcent tirds.

The purpose of this study was to examine soma asmects of the ecology of Sauvie Island, an extremely productive rabtor habltat located ten miles from Fortland, Cregon at the confluence of the Columbia and Wllamette Rivers(Flgure 1). specifically, I sought to determine the size and species comfosition of the raptor population and to identify the features of Sauvie Lsiand that allow it to supcort the great diversity of species and numbers of individuals as reflected in the findings of the annual bird count conducted by the fortland Audubon Soclety (see Appendix I). 
3
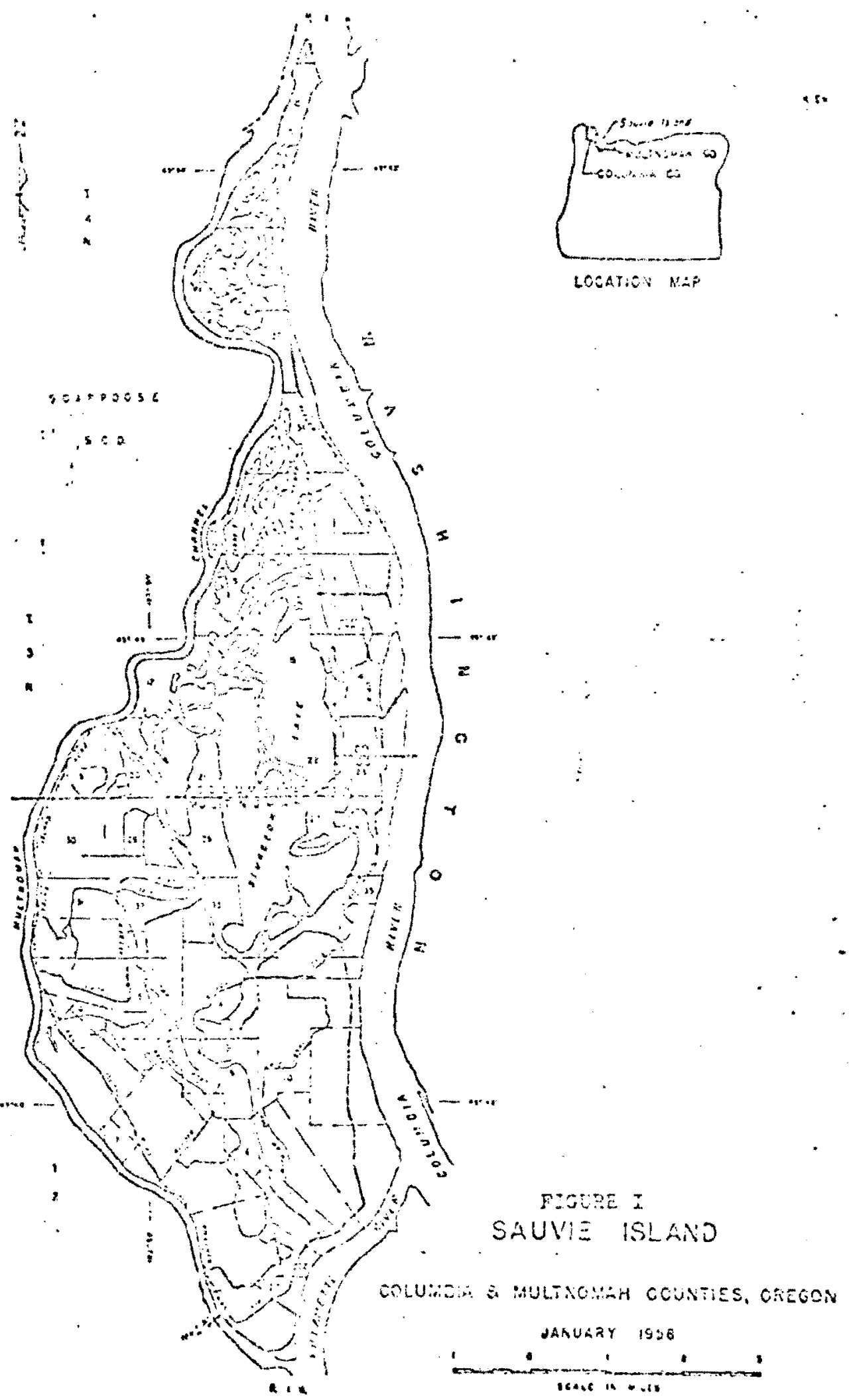
MATERIAIS AND WETHOLS

Description of the Study Area with Special Reference to Those Features Belleved to be Especlally Important to the Raptor. Fopulation

- More than half of Sauvie Island is owned publicly and managed by the Oregon State Game Comnission as game manasement areas for migratory waterfowl. (See Appendix II for a complete list of waterfowl specles recorded as stonolng at Sauvie Island.) Also resident to Sauvie Island are many specles of manrals. Among the specles of mammals that constitute notential raptor prey are Vagrant's Shrew (Sorex vagrans). Townserd Hole (Scapanus townsend11), Townsend's Vole (M1crotus townsend11), Eastern Cottontill (SyIvilazus floridanus), Cal1fornla Ground Squirrel (iperinochlius californicus), opossum (Dldeluhis marsuela115), Lone-talled Weasel (ilustela frenats), Iuskrat (Ondatra zivethlous) and domestic feral cats. Those mammals found on savie tsland that constitute potential competition for food (rodents, birds and carrion) include the coyote (Cans 1atrans). Red Fox (Vuloes fulva), Lonz-ta1led Weasel (Mustela frenata), Racoon (Erocyon lotor) and Opossum (Didel hie marsuetal1s).

As part of their program of habltat improvement the Game Comission plants large tracts of land to crops winch are 
left standing and some of which are intentionally flocded for the waterfowl. Wany farmers on the Islarad also engaxe in sinilar management practices, attracting waterforl to their land and then seling the right to hunt them. Between the Game complssion and the farmers a total of aporoximately 2200 acres of land is flanted for waterfow? and of this land more than half is flooded in the fall. Barley, Sudan, Frosso Mllet, Fall Barley, Buckwheat, Duckwheat, Smartwheat, Fotatoes, Jerusalem Artichokes and Corn are among the crops planted.

In addition to the cultivated species of plants, Sauvie Island hosts many species of native plants. Fecir (1941) sald of the vegetation of the Willamette ilver Valley, "The total. number of shrubs and herbaceous plants is larze, but there are $f \in W$ that are particularly characteristic of this area." Anone the cultivated flelds on bauvie Island are woodlcts consisting mainly of Black Cottonwood (Forulus trichorcarpa), oregon Ash (Eraxinus latifolia), Oreson Oai (quercus garryans) and Red Wllow (Salix lasitundra). The oaks represent the remants of a large stand that was logsed in 1945. Among the dralnage canals and in the wet, undiked areas are Elack dawthorne (Crataegus douglas11), western Red Dogwood (Comus ocoldental1s). Blackbcry (Bosa laclniatus) and Bitter Cherry (Prunus emaccinata). Surrounding many of the fieldis are fence rows of Clustered Wlid Rose (Rosa plsocarra). lec's (I04I) orovides a more compiete list of plant specles. Sauvle Island is a vory low-lying area (maximun elevation 
50 feet above sea level.) Thus, parts of the Island are fre.. quently covered by the fluctuating water levels of the columbla kiver. A levee system of canals and tiled flejds was constructed on the Island in 1942 to provide for aralnaze of flood waters. At the mouth of the Gilbert River (Flgure I), the main drainage waterway, is a pump station with the capaclty to pump 200,000 sallons per minute. It is this same system of canals and pumps that is used to flood selectively certain flelds during waterfowl migration season. Much of the Island is protected from flooding by the levees; however, there are still large flelds in the vicinity of Sturzeon Lake and on the north end of the Island that flood seasonally when the water level of the Columbla exceeds the 16 foot mark which represents the flood stage for sauvie Island. Figure II 1llustrates graphically mexlmum, minimun and mean ô the dally high water levels for a twenty year perlod by the U.S. Army Corps of Engineers at their recordlng guage at Vancouver. Wash1ngton, a few miles uo-rlver from Sauvle Island. As can be seen from Floure II, the flooding that look place on Sauvie Island the year of this study (1972) was not an uncommon occurance, but rather a more or less predictable, seasonal occurance. procedures and Equipment

The study was conducted in three phases. Fhase I entalled a census and food hablt study of diurnal raptors. Phase II entalled locating and ldentifying nests of Great 

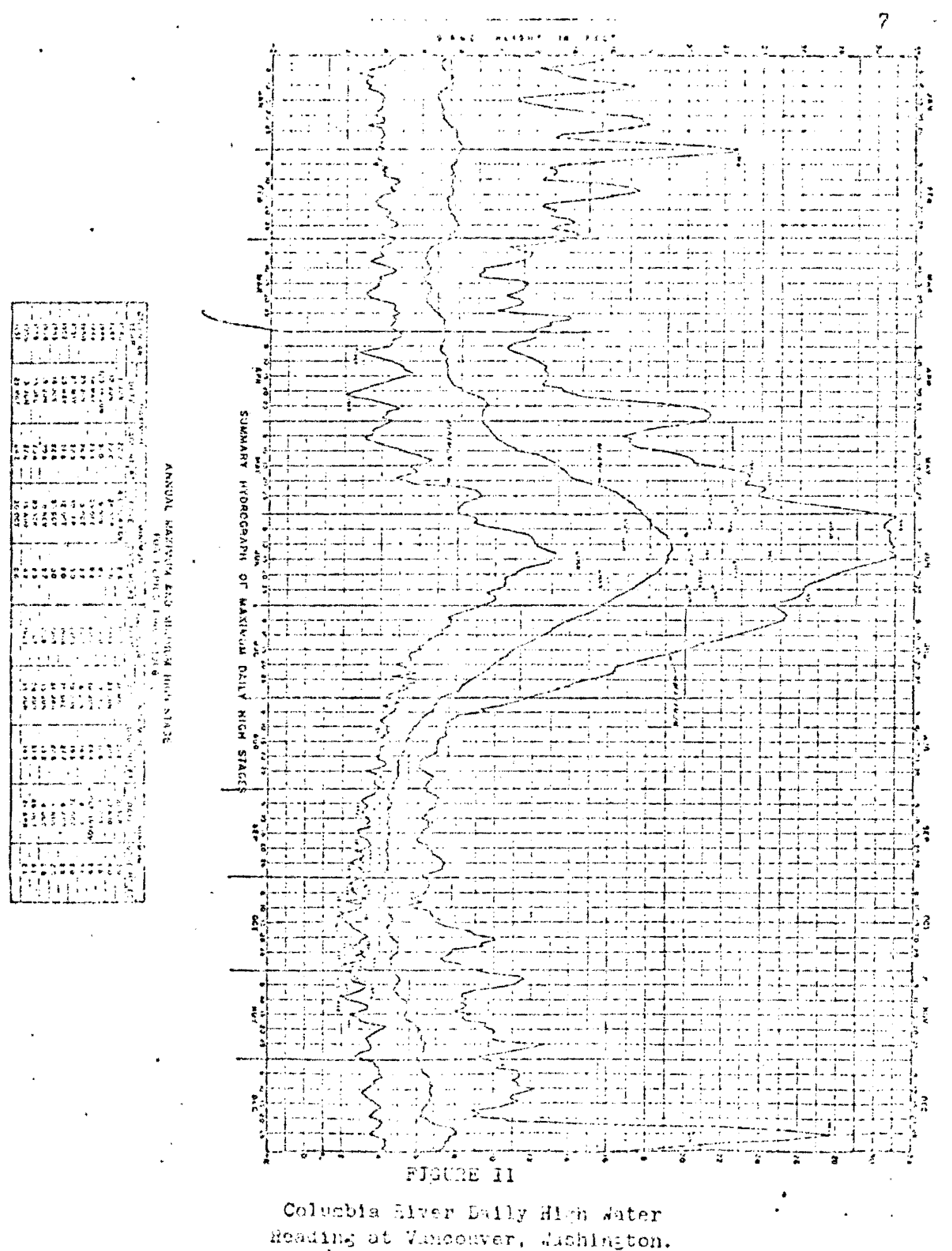
Horned OwIs and Red-ta1led Hawks and samoling 100 of the more than 3:0 nesting boxes found on Saurie Island. Fhase III entalled a population study of the major raptor prey species.

Fhase I began on January 13, 1972 and continued unt 11 March 16. 1972. It involved a census and food habit study of Redtail Hawhs (Buteo jamalcensis). Kestrel (Falco sparvarius). Bald Eagles (HaIlacetus leucocephalus), March Hawis (Clrcus cyaneus) and Short-eared Owls (As10 flamneus). In addition, note was taken of any rare or uncommon raptors that were positively identified in the study area during a phase of the study.

The census was conducted from a car which was driven over the entire roaded area of Sauvie Island ( $x_{p}$ oroximateiy 40 miles) at no faster than 30 miles per hour. Sensus trips were made twice weekly over two of three possible routes between the hours of 9:00 AM and 1:00 PM. All raptors sighted and their locations were recorded. Tasco $7 \times 35$ wide angle binoculars and a Swlft llodeI No. 821 (30X) spottins scope were used in the ldentification of birds ard in thase II for the location of raptor nests.

Food hablts were studied as follows. Once a week the ground under and adjacent to frequerted perches was cirefully searched for pellets. All pellets were collected and piaced in labeled bags for later laboratory ldetification of cortents, as done by Errington (1930). Whenever oossible huntIns birds were observed and an attempt was made to determine 
their prey. These observations were particularly lmportant In the case of the Redtail Hawks and Marsh Hawks because these specles digest most of the bone of their prey meking the pellets of little help in deternining food habdts, especlally in a quantitative sense (Errington 1930).

Phase II of the study whlch began in February 1972 and continued through early June 1972, Involved location and 1dentiflcation of Redtall Hawk and Great Horned Owl nests. During the winter the Redtall and Great Horned Owl nests of previous years were easily located, beinz very large and situated high in the branches of bare deciduous trees. These nests were closely watched for slans of nestinz activity. In addition, new nests were located as the mating Redtalls and Great iorned Owls constructed them.

In adiltion, 100 of the more than 300 nesting boxes, whlch were previously fastened to the trees at varlous points throughout the Island by the Oregon State Game Commission, were examined in order to determine the degree to which raptor specles were making use of them for nestino or, as in the case of the owls, roosting.

Phase III of the study was conducted in the months of January and February, 1972, the time of man-made flooding and during the montas of May and June, the tine of natural flooding. This part of the study included calculation of a population irdex of the major prey specles, and assessment of the effect that the fluctuating water levels had on their numbers and vulnerablilty. Also included in Phase III 
was a determination of the species composition ard census of owls, other than the Short-eared OwI whlch was ircluded in the census of diurnal raptors.

During the winter and spring of 1972 when the water levels on the Columbla River fluctuate Breatly, Museum Special traps were employed in flelds that were in the process of dralning so as to deternine how long it took for rodent nonulations to reestablish themselves in the previously jnundated flelds. Rodent latrines and runways were also used as indicators of the presence and relative numbers of rodents.

When flooding was at lts peak, a study was made of relative population densities of Microtus in study areas inmedlately adjacent to flooded fields compared to those in protected, non-flooded areas. An area 100 paces $10 n$ by 60 paces wide was staked out. Twenty sampling points were located in each study area using a random number table to determine the number of paces to be sterped off down the middle of the area. A coin was flipped to determine a turn to the rioht. or the left and then a random number deternined the number ef paces to move to the right or the left. This nethod made It equally probable for any glven point in the study area to be seiected for anaiysis. At the sampling foints stakes were arlver into the ground around whlch clrcles five feet In radius were circunscribed. Within these circles the presence and numbers of runways was noted and all rodent burrows, fresh latrines (1t takes approximately three days 
for the rodent droppings to become dark in color) and freshly nlbbled bunches of grass, characteristic of Mlcrotus were counted. This method was apolied in two flelds adjacent to flooding and two flelds not adjacent to floodinx. (Note: Census method sugested by Warren Aney of U.S.G.c.).

The census and species composition study of nocturnal raptors was carried out using a Uher 400 Report-I tape recorder playing owl calls taken from a commercial recording (Gün and Kellogrg 1962). When the calls were played within hearing range of most specles a response was eljolted. The routes described in Fhase I were driven once a week during: February and March for the oreat Horned $O w l$ census and in Aprli through June for the remalning snecies, including Screech Cwis (Otus as10) and Saw-whet Cwls (Aegolius acodica) and Barn Owls (Tyto alba). Since Barr Owls didn't respond as dependably to the recordinss as the other two species the Barn Gwi census was besed mainly on slghtings of their roadside hunting perches and their presence in barns during the daytime. At one mile intervals a recording of one species was played flve times with thirty second pauses in between playings to listen for responses. Recordings of so:e of the responses were made and were used to locate other owls "in the local dialect." The numbers and approximate location of responses were noted. If any other specles of owl was heard calling ther it was also noted and usually a recording of the species in question was played so as to keen the bird in the area until a sight identification could be riade. The 
Saw-whet CwI found in the study was located in thils way when It responded to a screech Uwl call. In ail cases, where there was some doubt as to the soecles of owl making a given cail, an attempt was made to lure the bird out into the open where positive identification could be made with the $21 d$ of $a s i x$ volt spot light. 


\section{RESUITS}

\section{Fhase I}

Bed-talled Hawks

after eight census trips it became apoarent that each of the 16-18 Red-talls frequented a certain huntine area. As can be seen from Table I, not every hed-tall was observed on every census trip. However, enough overlafping observations were made so as to be able to identify individual birds by means of their locations.

Due to their large size and their hablt of perching nore than 25 feet above the ground in Black Cottonwood, Oaks, Hillows and oregon Ash trees all of which were bare durlne the st.udy, the Red-talls were the most conspicuous raptors n

Sauvie Island.

Roush-1exzed Hoths

On four occasions Rough-legeed Hawks were observed in the study area. Their white heads, large slze and hablt of punping thelr wines and hovering made the Rough-legs easily Identiriabie. Dut to the spotty nature of Rough-leg observations ro food habit inforutation was obtalned for this species.

\section{Kestrels}

Fourteer. Kestrels were regularly observed hunting fron the powerlines that line the roads and the nerlmeters of the ficias, Not every kesirel was observed on every trin 
but enough overlappins observations were made to rermit; Identifloation of at lesst fourteen individuals. Bald Earles

Three Bald Eagles, two adults and one 1mature bird wers regularly observed in the area of sturgeon Irke. The Eagles had two favorite perching trees, a large oregon ash and an Cak, both of which were located nn Oak Island fsoe Figure I). At the base of these two trees was found the accurnulated remains of the Eagles' prey which seems to Indicate that the Eagles had made use of these perches for some tiae. On two occaslons all three Bald Eagles were observed whlle Ferching together in the same tree. Sharo-shirned Hawk

Cne sharp-shinned Hawk was observed in the study area on Fetruary 19. This was the only slighting of a sharp-shirned Hawk in the study.

Mer11r

on December 7 a verlin was observed snd photorraphed Ir a snag alone a roadway in the study area.

Harr:1ens

At least two or three harrlers were observed on most census trlos and the naximun number observed in one day was sever. However due to the karrlers' hunting and perchIng hablts they were one of the most diffloult of the Sauvle Islard diumal raptors to census accurately. Therefore the Harrier census may be a bit conservative. (See Discussion, Fhase I). 
Short-eared Owls

As can be seen from Table I the short-eared owl observations were spotty. However, at least once durinz most weets for the duration of the study one to as many as three Shorteared Owls were observed. Ilke the Aarrer, the shorteared Owls' perching and hunting habits make it a diffloult blrd to census accurately. Therefore the Short-eared OwI census may also be a blt conservatlve. (See Discussion, Phase I.)

Ferrusinous Hawk

A Ferruginous Hawk was observed and photographed on April 20. It was perched on a powerline pole and dia not fly off until I had stopped my car, gotten a good look at the blrd and taken a few photographs.

The flindings of the flnal part of Fhase I, the food hablt study are summarlzed in Table II. 


\section{TABLE I}

Census Data for Dlurnal Raptors on Sauvle Island, Decenber 1971-March, 1972

Date $\quad \mathrm{RT} \quad \mathrm{H} \quad \mathrm{K} \quad \mathrm{SEO} \quad \mathrm{E} \quad \mathrm{RI} * \quad \mathrm{FH} * \quad$ H* Dec. $7 \quad 27 \quad 6 \quad 13 \quad 0 \quad 1$ Dec. $23 \quad 16 \quad 7 \quad 15 \quad 0 \quad 1$ Dec. $24 \quad 19 \quad 4 \quad 11 \quad 2 \quad 2$ Dec. $\begin{array}{llllll}30 & 15 & 3 & 12 & 3 & 0\end{array}$ Dec. $3 i 20 \quad 4 \quad 14 \quad 2 \quad 3$ Jan. $\begin{array}{llllll}13 & 19 & 5 & 12 & 1 & 0\end{array}$ Jan. $\begin{array}{llllll}14 & 21 & 3 & 9 & 3 & 3\end{array}$ Jan. $20 \quad 20 \quad 5 \quad 11 \quad 3 \quad 1$ Jan. $21 \quad 19 \quad 4 \quad 10 \quad 2 \quad 0$ Jan. $\begin{array}{llllll}29 & 23 & 5 & 15 & 1 & 3\end{array}$ Jan. $\begin{array}{llllll}30 & 17 & 2 & 12 & 0 & 0\end{array}$ $\begin{array}{lllllll}\text { Feb. } 3 & 26 & 3 & 14 & 2 & 1 & 1\end{array}$ Feb. $8 \quad 10 \quad 2 \quad 13 \quad 0 \quad 0$ Feb. $\begin{array}{lllllll}12 & 17 & 2 & 12 & 0 & 0 & 2\end{array}$ Feb. $\begin{array}{llllll}13 & 16 & 2 & 11 & 2 & 0\end{array}$ Feb. $17 \quad \begin{array}{llllll}12 & 3 & 10 & 0 & 0 & 1\end{array}$

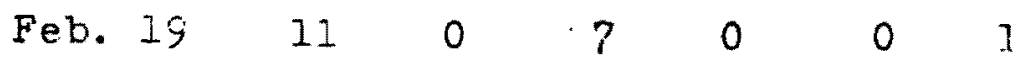
Feb. $24 \quad 14 \quad 7 \quad 17 \quad 2 \quad 0$ Mar. $2 \quad 13 \quad 4 \quad 17 \quad 2 \quad 0$ Nar. $3 \quad 28 \quad 4 \quad 11 \quad 3 \quad 0$ Mar. 8 Rain--Foor Visibility Mar. 9 Eain--Foor Visibility Mar. $11 \quad \begin{array}{llllll}18 & 3 & 12 & 1 & 0\end{array}$ 
17

TABLE I (Continued)

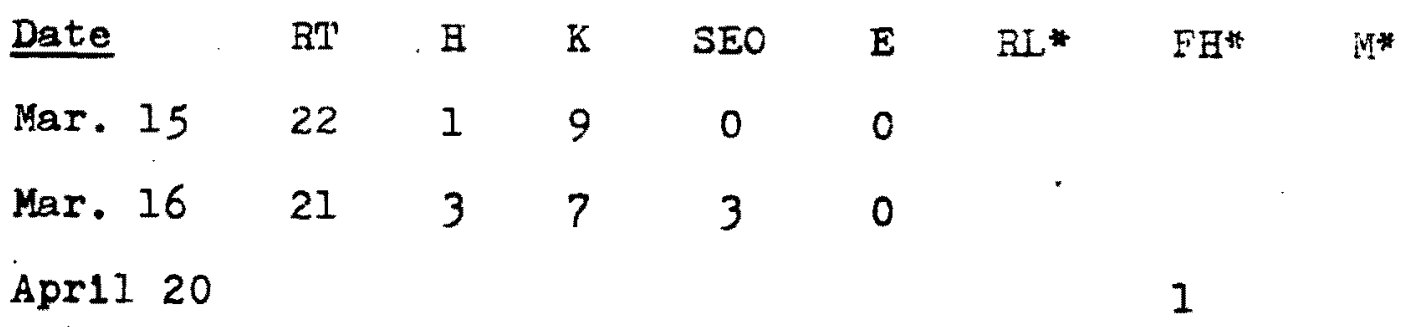

KEY TO SYMBOLS OF TABIE I

$\mathrm{RT}=$ Red-ta1I Hawk

$B=$ Earrier

$\mathrm{K}=$ Kestrel

SEO $=$ Short-eared OWI

$E=$ Eagle

$B I=\operatorname{Red}-1$ egsed tiawk

$\mathrm{FH}=$ Ferrusinous ilawk

$M=$ inerlin

* Indlcates four or fewer sightings 
TABLE II

Raptor Food Habjts as Determined by Frey Remains in Dellets and observations of Kills

Raptor Svecies Red-talled Hawk

Kestrel

Bald Eagle

Barr OWI
Erey

Sylvilagus floridenis

Microtus townsend11

Spermophilus beecheyl

Corrus brachyrhynchos

Passerine sp.

Didelphis marsurlal Is

Ducks

M. townsend11

Insects

Passerine sp.

Peroinyscus

Frogs

Ducks

Ducks

Carp

M. townsend11

Ducks

Sorex varrans

Insects

Fasserine $s p$.

Frozs

Scacanus townsend11

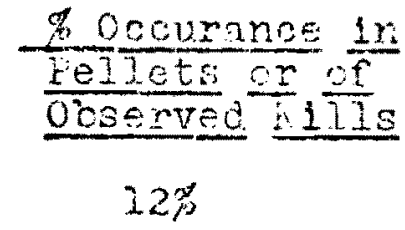

$65 \%$

$75 \%$

12,3

$6 \%$

$3 \%$

$3 \%$

647

$2+8$

15 th

$2 \%$

$27 \%$

$6 \%$

$100 \%$

$20 \%$

$100 \%$

5,

4,8

18

$.9 \%$

18

270 
TABLE II (Continued)

\begin{tabular}{|c|c|c|c|}
\hline Raptor Species & Frey & Feliets & $\frac{0 r}{11} \frac{o f}{11 s}$ \\
\hline \multirow[t]{5}{*}{ Screech OwI } & M. townsend11 & 456 & - \\
\hline & Fasserine $3 p$ & $20 \%$ & $\cdots$ \\
\hline & S. vasrans & $20 \%$ & \\
\hline & Frogs & $8:$ & \\
\hline & Ducks & $.9 \%$ & \\
\hline • & Insects & $20 \%$ & - \\
\hline \multirow[t]{5}{*}{ Great Horned OWI } & M. townsend11 & $30 \%$ & \\
\hline & Ducks & $14 \%$ & \\
\hline & D. marsupialis & $5 \%$ & \\
\hline & S. floridanus & $20 \%$ & \\
\hline & Carp & $6 \%$ & \\
\hline
\end{tabular}

$\frac{\text { accurance }}{\text { feliets or }} \frac{\text { of }}{\text { observat }}$ 
Thase II

A total of 18 Reatall Hawk rests were located in the study area. Nire of the nests were bullt in past years and were located prior to Harch 11, whloh was the earliest date that jedtalls were observed in nest bullding activities. Subsequent to March 11 nine new Redtall nests were found. These nests we e built 60 feet or nore from the ground, usually in Black Cottonwood trees although nests were found in orezon Ash and oaks as well. Due to the great helent ard seneral inaccessability of the nests I was unable to examine the nests closely.

Five Great Horned OwI nests were located on Sauvie Island. Three of the flve nests were located when the male Great horned owl was flushed fron his daytine nerch located close to the nest. In two cases male Great Horned owls were found on the ground directly urier the nest.

Nest Box Survey

of the one hundred boxes examined seven were found to contair screch Owls (1.e. the Owls were in the box when 1t was operea), another seven contalned screech owl peliets, flve contalned Earn ow I nests, another rine contalned Barn Owl pellets and four contalned Kestrel Nests.

Barn Ovls made use of the boxes durlng the winter as daytime perches and then nested in them during the soring. Some of the boxes showed signs of lono term orcunancy. One box contalred 580 Miforotus skulls in addition to an assortment of shrews, roles and passerine blrd remalns, while 
another nest contalned the remalns of a nesting Barn On'. In both of these boxes new nesting tonk riace in the suring of 1972. The nest boxes were tno small for both nerbers of a pair of Barn Cwls. However, In two cases nale and female Earn Uw.ls were found In adjolninz nest boxes on the same 11 ab of a tree.

screech ciwls also nade use of the nest boxes for perchins and nesilin. In some cases the screech owls made use of more than one box during the winter. In two instances where clusters of nest boxes were repeatedly sampled certain individual screech owls were found in every box in the cluster at one time or another. It is also of intercst to note that jcreech iwls nested for at least two years in natural cavities and hollows in trees that also contained nest boxes. In both instances, however, the cwls srent the winter perching in the nest boxes when the hollows were fliled wlth water from the alinost dally winter ralns.

Four nestrel nests were found in nest, boxes. Ilke the Barn Owls and the Screech Owls, Kestrels normaliy nest in hollcws snd natural cavlties in trees. Fhase III

population Index of wajor Irey Species

Duchs...The creach state Game Commission records show that approximatedy 20,000 waterfowl are baszed each year by hunters (Annual Benort of the Jane Division, C.S.G.C.). Furthermore, 1t is estimated that $20 \%$ of the b1rds shot are wounded and die at a later time, never actually baszed by the hunter 
(John Chattin, Bureau of Sport's Fisheries and Wlidlife). In addition, there are still more waterfowl. that succomb to Jead polsoning caused by the ingestation of shot while dabbling in the mud (Chet Kebby, 0.3.C.C.). This sugrests that on Sauvie Island approxinately 5000 dead and wounded ducks may be avallable during and just after hunting season for consumetion by raptors or other opportunists.

Microtus--During the winter months when the flelds were relatively barren, the runways used by the Townsend's Vole (M1crotus townsend1) and the Vagrant Shrew (Sorex vagrans) became apnarent aimost, everywhere in the study area. The flelds took on the appearance of glant leaves with veins running out in all directions.

Although both specles made use of the runwoys, Microtus became the species of interest due to its high occurance in the pellets of all resident raptors.

Table III glves the results of trapplng and observations in previously flooded flelds for flve days following drainIng of superficlal water. As can be seen fron Table III quite a sizeable icrotus population had migrated from the lush vegetation in areas adjacent to flooding to the relatively barren habitat of the previnusly flooded area.

Flgure III gives the findings of indicators of Mlcrotus activity in flelds adjacent to flooding and flelds not adjucent to flooding. Evidence of Microtus activity was found in all twenty sample olots adjacent to flooded areas. As was prevlously stated in the Methods section, the sample 
TABIE III

Results of Trapping ( 30 Mraps) and observations (30 Samples)

In Previously Fiooded Flelds for Flve Days Following the

Dralning of Above-Surface Water.

$\begin{array}{lcl}\text { Day } & \text { \#Latrines } & \text { Traoning gesults } \\ 1 & 3 & \text { None } \\ 2 & 7 & 1 \text {-Sorex vaxrans } \\ 3 & 18 & 2 \text {-M1crotus townsend1 } \\ 4 & 25 & \text { None } \\ 5 & 28 & 2 \text { - Hidcotus townsend1 } \\ & & 3-\text { Sorex varans }\end{array}$




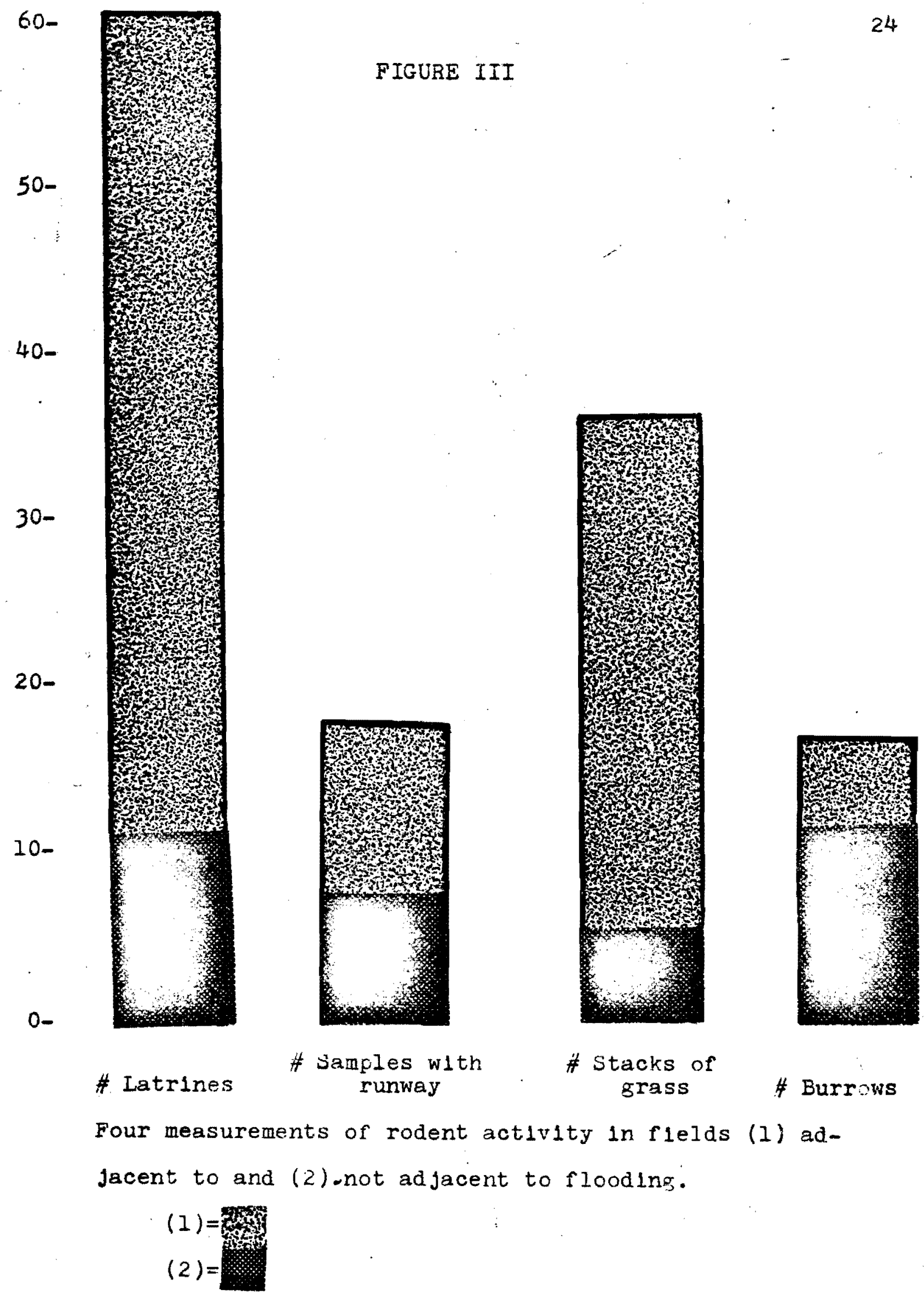


plots were 73 square feet each. Using an estimate of two Mlcrotus per olot (wich seems reasonable due to the number of runways, latrines, etc. and extramlating I arrived at an estlmate of 558 N1crotus per acre.

Owl Census--Table IV gives the estinated populations of four of the flve owl species found on Bauvie Islard. The fifth specles, the Short-eared Uwl was included along with the diurnal raptors in Fhase $I$. 
TABLE IV

Species Composition and Census of Cwls on Sauvle Island

Specles

Barn Owl

3creech Ow]

Great Horned Owl

Saw-whet Owl
Number of Individuals

16

20

12

2 


\section{DIUCUSSION}

Fhase I

Red-ta11s

Gabrielson and Jewett (1940) noted that the Red-ta11

was the most common large hawk in Oregon. in is was also found to be the case on Sauvle Island where slx or seven Kedtalls could sometimes be seen along a mile stretch of road during the winter months. Cralghead and Craighead (1961) observed that Red-talls maintained regular winter ranges but did not defend them in a territorlal manner as is the case during breeding season. Consequently, the winter ranges often overlapped. On Sauvie Island during the winter of 1972 there were often times areas of hish coricentrations of Red-talls. For exanple, on 29th of January eleven Redtalls were observed in less than three miles of driving along Oak Island Road (Figure 1); that same day seven Redtails were observed from the top of the dike along IIttle Sturgeon lake.

Eamlin and Grossman (1964) noted that high rastor concentrations may of ten reflect high concentrations of prey. Starting three days before the hurricane of 1938 In New England, Hamlin and Grossman reported seeing large numbers of rodents crossing roadways and olimbing hillsides, possibly in response to the faling baroneter. 
Also durine this period of time they reported seeing large numbers of Red-tall Hawks.

Considering the fact that eighteen active Red-ta11 nests were eventually found on Sauvie Island it seems quite likely that most of the winter population remained on Sauvie Is land and nested there. Eough-legsed Hawks

The Rough-legged Hawks nest in the Arctic and are belièved to migrate south in response to fluctuating lemming (Synaptomys spp.) and Snowshoe Hare (Lepus americanus) populations (Iack 1954). The four observations of Rcughlegsed Hawks probably represented one or two southward wanderinx individuals.

Because of the sparcity of Rough-leg observations no food hablt data was obtained for this species. Kestrels

Gabrielson and Jewett (1940) sald of the Kestrel, wris handsome little falcon is without doubt the nost, abundant raptorial bird in the state and is a familiar sisht to nost travelers as it perches on the telephone poles along the highways, now and then darting to the ground to get a mose, a beetle, or a orasshopper detected by lts keer eyes." on Sauvie Island, the Kestrel is second only to the Red-tali In abundance and as was observed by Gabrielson and jewett they can of ten be observed perching on powerlines. In the study area there are powerlines that stretch across and around the perimeter of the cultivated fields where prey 
is abundant. Being the smallest of the diumal raptors, the Kestrels are the only specles small enourh to effectively make use of the poverilnes as hunting perches. It is quite possible that the presence of the powerlines in prime hunting territory has contributed to the success of the Kestrel on Sauvie Island.

\section{Harriers}

Harrlers were a most difficult bird to census accurately. They are reported to have one of the largest winter ranges of all the North Amerlcan raptors (Cralghead and Craighead 1969). One tarrier was flying parallel to a roadway and was kept in sight for four and a half miles. An added complication in the Harrier census was their hablt of perching on the ground, out of sight in a rormal cerisus situation. Cralghead and Cralghead (1969) found that the Harriers in their study area in flchigan spent an average of $57 \%$ of their time on the ground. To compensate for this shortcoming the Craigheads carried out a foot census in a number of areas that they had previously censused by car and ther! comparing both census figures calculated that the car census flgures should be multiolled by 2.3 to glve a more accurate estimate of the number of Harrlers. I made no quantitive studiss of the arount of time that Harriers spent on the ground. However, 17 of the 4.1 Harrlers recorded Ir the census were on the ground and the remaining blrds were flying close to the ground and were not visible at a lone distance. Therefore it is quite possible that the 
Harriers also nest, on the ground which is a disadvantage in an area of periodic flooding juring nesting season. Ikis is probably the reason why Harriers are not known to nest on Sauvie Island.

Bald Easlos

Gabrielson and Jewett (1940) reported that the Bald Eagle was tecoming rare in uregon. However, they made speclal mention of the Columbla River Valley as a place where Eagles were falrlÿ regularly observed.

On Sauvie Island the Earles' presence at Sturgeon Lake colncided with the influx of large numbers of mlgrating: waterfowl whlch constituted their major food source. Short-eared Owls

The Short-eared Owls are listed by Bent (1.937) as permanent residents of oregon. However, like the jarrlers they are ground percining and ground nesting blrds which makes survival on sauvie Island during nesting sesson a most difficult if not limpossible task due to the flooding of rany of the fields.

Because of their eround perching hablt the shorteared ow is a difflcult bird to census accurateiy. For this reason the census flgures for the short-eared ow may be a bit conservative. Phase II Nest Eox jurvey

For many yoars it has been known that owls w1ll nest in man-made struotures of varlous sorts. People who desired 
to encourase the growth of the ow] population because of their fantastic mouse-catching abilitiss have constructed shelters for owls and even made provision for owls within the desirn of their own homes. Ir the Netheriaris farmers have for years bullt access routes to the lofts and roof spices in their houses. Large Friesin farmhouses of ten are bullt with a decorative complex or the roof called an "OwI board" (oelegat) (Sparks and Soper 1970).

Southern (In Lack 1966) successfully used nest boxes to study the nesting behavior and population to the Tawny Owl (Strix aluca) in Great Britain and it is a common practice among wildife conservationists to construct nest boxes for specles of owls that would normally nest in the hollows of trees.

The nest boxes on Sauvie Island are prlmarily intended for Wood Dicks (Alx sponsa), however according to Frank Newtor, Game Conmission man in charge of Sauvie Isiand, boxes are placed in many different habltats so that they get a wide varlety of residents.

Beceuse a relatively small proprotion of the resident, Barn Uwls, Screech Owls and Sparrow nawks made use of the nest boxes, it is belleved that the boxes do not consilute prime nesting and/or perching sites for these species. That 1s, given the cholce it seems that these blrds choose to nest or perch in relatively dry natural oavitles than in nest boxes when both are avallable. However, the fact that there are hundrers of avallable boxes susgests that no 
Kestrel, Screech 0 w or Barn Cwl would forego neting for want of an adequate nest site. Furthernore, lt seemi poss1 ble that the nest boxes allow these three scecles to rest. earlier in the ye r than they would in the natural hollows because all of the nests found in hollows wer in the onenended stump of large limbs that had broken off, leavinx a deep, water-tight hollow pointing upward.

Phase III

Pooulation Index of Major Erey Species

Ducks--Although ducks appeared to constltue a relatively small part of the food consumed by raptors over the course of a year, they were a cominon food ltey for all snecles of raptors on Sauvie Island during and for about three weeks after duck hunting season. Errington (196, found that raptors often fed on crippled waterfowl during hunting season.

The fact that no evidence of duck feathers in ractor pellets was present four weeks after hunting season (nor was it present before hunting season) was interpreted as meaning that raftors were frobably feeding exclusively or woundea ducks and carrion and were not oreying unn heal thy duc's. It would seem unlikely, for example, that nestr 1 s and screech Owls, both of whlch fed on ducks, could kill healthy ducks which were swift fliers and at least twice as large as these two species of raptors.

An observation of a hunting Harrier also lends suprort to the claim that the raptcrs fed on wounded ducks. I watched 
the bird Ir question fly from pond to pond and scare uo flock after flock of duc'ss. The Earrier did not make any attempt to capturs the ducks as they flew off. However, at one pond a duok was unatle to fly off with the rest of the flock and mereiy splashed about in the water. The Harrler quickly swooped down, made the k111 and proceeded to consume its catch.

With 5000 wounded and dead ducks avallable the raptors were probably not even competing with one another for nrey but merely partaking of the same over-abundant "free food."

Microtus--See general discussion.

Owl Census--The census data in Table IV represent positively iden ifled and consistent?y observed indiriduals. In some cases palrs of owls were located in their nestins areas in which case they could also be located during the day. Other individuals were located at their nocturnal perching soots and were repeatedly lncated after dart by the method described earlier.

Because many Screech OwIs and Great Horned Owls consistently responded to the taped calis even when I was in plain sight and as ciose as fifteen feet, leads me to belleve that the cersus method used was highly effective for these two species.

It is difficult to commert on the accuracy of the Barn Owl cersus whlch was based on sitting due to the fact that Barn Owls whlch were under observation did not rescond to the recorded Barn Owl call. Also, the Barn Owls, very con- 
venlently made use of the roadside fenceposts at night for huntine erches so that their white colnr could be very easily seen from a passirg car. The twelve Barn owls listed in the census were found to frequent certain perches as evidenced by the accumulated pellets and prey remalns under certain fenceposts and in certain barns.

only one Saw-whet $O w$ was positively identified in the census. This one Individual responded to a sereech ow].

cail and was then lured on to a nearby tree where a nositive Identification was made. According to Gabrielson and Jewett (1940) the Saw-whet was never a commonly occuring blrd in the Columbia River Valley and the census figure of two may not be far from correct. (The one bird was heard and seen during matinz season therefore I took the liberty of adding a second bird to the census).

Due to the fact that there seems to be a great demand for owls as pets or specimens, I have not listed the jocation of the individuals that I have found. 


\section{GENERAL DIBCUSSIUN}

The combination of a number of factors makes Sauvie Island an unusually rich habltat for raptorlal birds. Among these are: (1) the planting and periodic flonding of thousands of acres of crops whlch at first allows Voie populations to reach hlgh numbers and then crowds them into the remaining dry land where they are exceedinly vuinerable to predation; (2) the wounding and/or lead poisonins of approximately 5000 ducks each huntins season which provides an enormous free food supply for all raptor species; (3) the ideal hunting and nesting habitat of open flelds, dotted with dense st,ands of timber used by all species of raptors for nesting and/or perching and (4) the powerIInes and fenceposts that stretch across the Island that are used by Kestrels by day and the Barn Owls by nisht for hunting perches. In addition, the nest boxes nrovided uy the orego: State Game Commission and the barns on Sauvle relard provided hundreds of well protected perchlne sites for Barn Owls and Screech owls and nesting sites for the Barn Owis, Screech Cwls and Festrels. Fer-. haps the nest buxes eliminate the lack of nesting sites as a posslble limlting factor for the scecles that normally nest in hollows in trees, in adaltion to permitting these specles to nest earlier in the year. 
The results of the food hablt study revealed that Townsend's Vole constituted a significant propoition of the fand 1tems of ali resjdent specles of raptors on Sauvie Isiand. At flrst glance this situation would seem to be a contradiction to Gause's Rule (1934) which is widely accented by contemporary ecologists and has been shown to hold true for many sfocles of blrds and mammals (Lack 1944, 1945, 1946). Gause's thesis was that two specles with the same ecology cannot persist together in the same region. (See Cromble (1945) for a detalled mathematical treatment of inter-. speciflc competition). However, throughout the years a number of special cases of Irterspecinic competitions involvins various predators and prey specles belonging to the zenus M1crotus and other extremeiy proliflc specles have been documented (Errlngton 1935, Iack 1946, Lockle 1955). Many parallels can be drawn between the findings of the above-mentloned workers (especially Lack) and the findings of the study; for this reason Lack's explanation of the apparent contradiction of Gause's Rule in the case of certain European Raptors might also be apglied to the situation cr. Sauvie Island.

Lack (1946) stated that "...elther they (raptors) differ in habltat, in which case trelr hunting methods and/or the size of their prey are different." Lack reported that with only one exception no two congeneric Eurccean raptors compete for the same food supply. Furthermore, In twelve specles of different genera he found no 
overlap in these species. However, for five specles of Strigiformes and five specles of Falconifurmes Iock found an apparent contradiction to Gause's inu? The buly of the food of these raptors consisted of the vole. Microtus arvalis. This situation apnears to be nearly a direct paralif I to that on Sauvi: Island. It is interesting to note that three of the species in Iack's study--the Barn Owl, the darsh liawk and the short-eared Owl--are al so aredators of a species of lilcrotus on Sauvie Island. In add1tion, Lack listed the European Kestrel (Falco tinnuculus). which is the ecological equivalent of the Amerlcan kestrel (Falco sfarvarius) and the Buzzard (Buteo buteo), a congener of the Red-talled Hawk (Buteo jamalcensis) (Grossman and Hamlet 1964).

In order to reconclie the differences between his findIngs and Gause's Rule, Lack put forth a corollary to Gause's guie, that "...two specles can exist together in the sane habltat and eatine the same food when the fonds In question are temporarily so much more abundant than the requirements of the consumers that the latter do not effectlvely compete with each other whlle eating thein; and to is may still hold true even if the food in question temorarliy provides the bulk or even the whole of the diet of the specles Involved." Lack also stated that the large percentage of Mcrotus in the prey may be "unnatural and due to man." lack cltes replacement of swamps by grasslands and cornfleids as man-made changes that encourare Mlcrotus 
populations, thereby increasing the percentage of Microtus in the prey of raptors.

That overpopulation of a prey specles leads to the prey species being heavily preyed upon is not a new or recent finding. McAtee (in Errington 1935) aövanced the principle that "predation tends to be in proportion to population" and also postulated that the froportion rises and falls with the numbers of avallable food organisms. * Errington (1935) specifically stated that HcAted's principle was applicable in the case "the prolific vertebrates." Lockle (1955) found that Short-eared Owls (Aslo flammeus) fed alnost exclusively or Microtus during what he termed a "vole plague."

The work of McAtee, Errington, Lack and Lockle lends support to the conclusions drawn from the data of the present study. The diking and draining of Sauvle Island and the cutting of oaks and the planting of croos could make for an "unnatural" condition similar to that described by Lack (1.946). The perlodic flooding of many flelds could then concentrate the Voles even more making them the most abundant and avallable raptor prey on Sauvie Island. Therefore Lack's Corollary to Cause's Rule and McAtee's Principle could very likely apply to the oredation of Mlcrotus townsendi1 by the various srecles of raptors on Sauvie tsland. An account of flooding causing an increaded vulnerablity to predation in Microtus norulations was recorted by Izotov (In Elton, Ig/42). Izotov conducted an experiment whereby 
a large number of voles of the specles M1crotus arval1s were trapped. ringed on their hind legs and then released with the hope of recovering the rings from owl pellets that he collected at the ow].s' perchins sites, so as to deteringe the percentage of voles eaten by the owls. No sconer had Izotov completed the ringinz than the River Dnieper flooded, drivins the rodents to higher ground where "Owls attacked them." In1t1ally Izotov estimated the ocouiation of Mlcrotus arvalls at 58 per acre; after one month he estlmated the population to be nine per acre, an $90 \%$ reduction in sumbers. On Sauvie Island, however. tha land and wildife management practices that gererate such large numbers of Microtus are practlced every year and baring some intrinsic cycle in the numbers of Microtus It is quite Ilkely that ilcrotus numbers and density will continue to be very high during all seasons of the year with especiaziy dense populations during times of floodins. According to Cralghead and Cralghead (170,) all saccles of raptors in their study area (including Redtalls) were closely correlated with the population(s) of theli chief winter food(s). If this conclusion is true for my study area then baring any changes in manarement practices, Sauvie Island should continue to attract and sunnort high numbers of raptorial birds. 


\section{AFPEIDIX I}

Iist of Raptors jichted in the Audubon Christmas Bird Census on Sauvie Isiand, 1967-1971.

\begin{tabular}{|c|c|c|c|c|c|}
\hline Spec1es & 1067 & 1363 & 1067 & 1370 & $107 ?$ \\
\hline Red-Talled hawk & 54 & 69 & 81 & 82 & 61 \\
\hline Rough-Le e ged Hawk & 4 & 5 & 3 & 2 & 6 \\
\hline Cooper's Hewk & 2 & 4 & 6 & 1 & 9 \\
\hline Shąrp-Shinned Hawk & 1 & 2 & 3 & 2 & 2 \\
\hline Kestrel & 78 & 86 & 92 & 102 & 98 \\
\hline Merlin & 0 & 1 & 1 & 0 & 0 \\
\hline Peregrine Falcon & 1 & 2 & 2 & 2 & 0 \\
\hline Gyr Falcon & 0 & 0 & 0 & 1 & 0 \\
\hline Harrler & 10 & 18 & 13 & 18 & 20 \\
\hline Bald Easle & 1 & 2 & 3 & 3 & 3 \\
\hline Barn Cwls & 2 & 6 & 7 & 11 & 7 \\
\hline Soreech Cins & $i$ & 2 & 1. & 1 & 0 \\
\hline Creat Eorred Cwls & 2 & 11. & 5 & 11 & 3 \\
\hline Lone-eared uwl. & 1 & 0 & 0 & 0 & 0 \\
\hline Short-eared Owl & 4 & 5 & 4 & 16 & 2 \\
\hline Saw-whe: OwIs & 0 & 0 & 2 & 0 & 0 \\
\hline
\end{tabular}




\section{AFPENDIX II}

List of Migratory Waterfowl that are iunted on Sauvie Island

Mallard

Am. Wldgeon

E. Widgeon

Green-winged Teal

Pintall

Shoveler

Gadwall

Clnnamon Teal

Wood Duck

Ruddy Duck

Goldeneye

Bufflehead

Ringed-neck Duck

Lesser Scaup

Canvasback

Redhead

H. Merganser

Conmon Merganser

White-winged scoter

old squaw

Canada Goose

White-fronted Goose

Snow Goose 


\section{SUMMARY}

1. Four siecles of diurnal raptors and three scecies of nocturnal raptors were regularly slghted in falrly high numbers on Sauvie Island during the winter and spring of 1972.

2. Four additional diurnal raptors and one species of nocturnal raptor were less commonly identifled.

3. All snecles of raptors for which fond habit, information was obtained, with the excention of the Bald Eagle, were found to feed on the vole, Mlcrotus townsendi, during: every month of the study.

4. All species of raptors fed on ducks durint and lmmediately after duck hunting season which seemed to indlcate that raptors were feeding on carrlon or wounded ducks.

5. The population of microtus was found to be extremely hlgh especlally in areas adjacent to flooding. A conservative estimate of 558 Mlcrotus per acre was made for an area adjacent to flooding.

6. The common practice on Sauvie Island of planting ilelds of srain and then intentionaliy flooding them (for waterfowl use) was found to be a major factor in the numbers and vulnerability of Microtus.

7. Durlng the duck hunting season annroximately 700 ducks are sinot, not retrieved by hunters and therefore avail- 
able to raptors and other opportunists.

3. Barn uwls (Tyto alba), Screech CwIs (0t1s asio) and Kestrel (Falco sparvarius) made use of the nest boxes on Sauvie Island.

9. The hich degree of overlapping in the food habits of Sauvie Island raptors was found to be very similar to cases reported for European raptors in times of high vole populations. 


\section{REFERENCES CITED}

Bent, Arthur Cleveland. 1937. Life Historles of North American Birds of Frey, Volumes I and II. U.S. Government Frinting offlce, Washington D.C., $949 \mathrm{~F}$.

Cralghead, John J. and Frank C. Cralghead. 1969. Hawk, Owls and Wlldilfe. Dover Fublications, New York. $443 \mathrm{p}$.

Cramp. S. 1963. Toxic chemlcals and birds of prey. British Birds, 56: 124-139.

Cramp, S. and F.J. Conder. 1963. Deaths of birds and mamrals from toxic chemicals, September 1961-Auxust 1962. In: The third report of the Joint Commlttee of the British Trust for Ornithithology and Royal society for Frotection of Birds on Toxic Chemicals, in collaboration with the Game Research Assoclation.

Dewltt, J.B. and J.J. Buckley. 1955. Studies on pesticlde-Eagle relationships. Interim refort to the National Audubon joclety convention, Corpus Cnristle, Texas. In: British Birds, 56: 139.

Elton, C. 2.942. Voles, Mice and Lemmings. Clarsndon Press, Oxford, $1366 \mathrm{p}$.

Errinston, raul L. 1930. The pellet analysis method of raptor food hebits study. Condor, 32: 272-276.

Erringtor, Faul L. 1935. Over-populations and oredetions: a research field of sinzular promise. Condor. 37: $230-232$.

Errington; Eaul L. 1969. Of Fredation and Life. Iowa State Unlversity Fress, Almes, $350 \mathrm{p}$.

Ferguson-lees, I.J. 1963. Changes in the status of birds of prey in Europe. British Birds, 56: 140-148.

Fltch, i.j., F. Swenson and D.F. Tillotson. 1946. Behevior and food hablts of the ied-talled Hawk. Condor, 48: 205-237.

Gabrlelson, I. and Stanley Jewett. 1970. B1rds of the Pacific Northwest. Dover Eublications, NewYork, $630 \mathrm{p}$. 
Gause, G.F. 1934. The Strugzle for Ex1stence. Hafner Fublishing Company, ivew York, $163 \mathrm{p}$.

Grossman, Mary L. and John Hanlet. 1964. B1rds of Frey of the World. Bonanza Books, lew York, 436 \%.

Gunr, willian and Feter Faul Kelloss. 1962. A Fleld Gulie to Western Bird jonss. Houghton Mifflir Company, Boston.

Jeffrics, U.J. and I. Frestt. 1966. Fost-mortem of pereerines and lanners with particular reference to organochlorine residues. British Blrds, 59: 49-64.

Lack, Dav1d. 1945. The ecology of closely related soecles with sueclal reference to the cormorant, Fhalacrocorax carbo and shag. $F$ aristotelis. Journal of Animal Ecology, 14: 12-16.

Lack, David. 1946. Competition for food by birds of prey. Journal of Animal Ecology, 15: 123-129.

Lack, David. 1954. The Natural Resulation of Anima] Numbers. Clarendon Fress, Oxford, $343 \mathrm{n}$.

Lack, David. 1966. Fopulation Studies of B1rds. Clarendon Press, oxford. $138 \mathrm{p}$.

Lockle, J.D. 1955. The breeding hatits of Short-exred Owls after a vole plague. B1rd study, 48: 253-250.

Oregon State Game Comnission. 1965-1771 inclusive. Annual Report of the Game Division.

Orlans, G. and F. Kuhlman. 1956. Red-talled Hawk and Horned OWl populations in Wisconsin. Condor, 58: $371-385$.

Peck, M.E. 1941. A Manual of Higher Flants of Oregon. Metropolitan Press, Fortland. 866 p.

Peterson, Roger. 1961. Fleld Gulde to Blrds, and Edition. $\mathrm{J}$. Houghton Miffiln Compary, Boston. $366 \mathrm{~F}$.

Ratcliffe, D.A. 1967. Decrease ir eggshell welght in certain birds of prey. Nature, 215: 208.

Royal Soclety for the Frotection of Blrds. 1965. The ifth report of the Jolnt Complttee of the British Trust for Crnitho?ory and The Royal. Soclety for the Frotection of Birds on toxic chemlcals, August 1063Juily 1964. 
Sparks, John and Tony Soger. 1970. Owls, The1r liatural and Unnatural Aistory. Taplinger Fublishing Comrany. New York. $206 \mathrm{p}$.

Wynne-Edwards, V.C. 1960. The overfishins princigle applied to natural copulations anc their foot resources and a theory of natural conservation. Eroceedings of the Internationa? Ornithologicel Congress.

21mmerman. David E. 1971. Last hope for the csrreys of Iong Island Sound. New York ifmes, December 12: 39. 